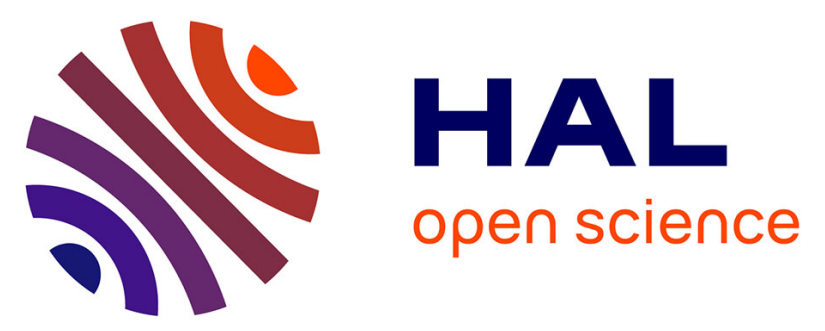

\title{
Estrogens and their receptors in breast cancer progression: a dual role in cancer proliferation and invasion.
}

Nadine Platet, Anne-Marie Cathiard, Michel Gleizes, Marcel Mg Garcia

\section{- To cite this version:}

Nadine Platet, Anne-Marie Cathiard, Michel Gleizes, Marcel Mg Garcia. Estrogens and their receptors in breast cancer progression: a dual role in cancer proliferation and invasion.. Critical Reviews in Oncology/Hematology, 2004, 51 (1), pp.55-67. 10.1016/j.critrevonc.2004.02.001 . inserm-00144757

\section{HAL Id: inserm-00144757 https://www.hal.inserm.fr/inserm-00144757}

Submitted on 7 May 2007

HAL is a multi-disciplinary open access archive for the deposit and dissemination of scientific research documents, whether they are published or not. The documents may come from teaching and research institutions in France or abroad, or from public or private research centers.
L'archive ouverte pluridisciplinaire HAL, est destinée au dépôt et à la diffusion de documents scientifiques de niveau recherche, publiés ou non, émanant des établissements d'enseignement et de recherche français ou étrangers, des laboratoires publics ou privés. 


\title{
Estrogens and their receptors in breast cancer progression: a dual role in cancer proliferation and invasion
}

Nadine Platet, Anne Marie Cathiard, Michel Gleizes, Marcel Garcia

Institut National de la Santé et de la Recherche Médicale, INSERM Unité 540, Molecular and Cellular Endocrinology of Cancers and University Montpellier I, 60 rue de Navacelles, 34090 Montpellier Cedex, France

\begin{abstract}
Estrogens play an important role in regulating the growth and differentiation of normal, premalignant and malignant cell types, especially breast epithelial cells, through interaction with two nuclear estrogen receptors (ER $\alpha$ and $E R \beta)$. In this review, we present a brief overview of the actions of estrogens in the different steps of breast carcinogenesis, including cancer progression to metastasis, and of their clinical consequences in the prevention, prognosis and treatment of the disease. The requirement of estrogen receptors, mainly of the alpha subtype, in normal mammary gland differentiation and growth has been evidenced by estrogen receptor deficiency in animals. The promotion of breast cancer carcinogenesis by prolonged exposure to estrogens is well-documented and this has logically led to the use of antiestrogens as potentially chemopreventive agents. In breast cancer progression, however, the exact roles of estrogen receptors have been less well established but they may possibly be dual. Estrogens are mitogenic in ER-positive cells and antiestrogens are an efficient adjuvant therapy for these tumors. On the other hand, the fact that estrogens and their receptors protect against cancer cell invasiveness through distinct mechanisms in experimental models may explain why the presence of ER is associated with well-differentiated and less invasive tumors.
\end{abstract}


1. Introduction

2. Expression of estrogen receptors in normal, premalignant and malignant mammary tissues

2.1. Normal mammary gland and premalignant lesions

2.2. Invasive breast carcinoma: ERs as prognostic markers of primary breast cancers

2.2.1. ER $\alpha$ is associated with a favorable prognosis in primary breast cancers

2.2.2. Expression of estrogen receptors beta

2.2.3. Expression of receptor splicing variants

3. Estrogens and their receptors in breast cancer progression: a dual role in cancer proliferation and invasion

3.1. Estrogens increased ER-positive breast cancer cell growth

3.1.1. Direct evidence of the mitogenic effect of estrogens

3.1.2. Involved mechanisms?

3.2. Are the anti-invasive effects mediated by estrogen receptors responsible for their association with a favorable prognosis of breast cancers?

3.2.1. Clinical data supporting the hypothesis that estrogens prevent invasion

3.2.2. Estrogen receptors inhibit invasion through two distinct mechanisms in the presence or absence of hormone

3.2.2.1. Estrogens inhibit invasion via ERE-regulated genes

3.2.2.2. Estrogen receptors inhibit invasion independently of ligand binding: involvement of protein-protein interactions

3.3. Role of estrogen receptor variants in cancer progression?

3.3.1. Splicing variants of ER alpha and beta

3.3.2. Mutants with point mutation

4. Antiestrogen approaches for breast cancer therapy and prevention

4.1. Tamoxifen and other adjuvant therapies of breast cancer

4.2. Aromatase inhibitors

4.3. Second therapy for antiestrogen-resistant tumors

4.4. Implication of estrogens in breast cancer carcinogenesis and the use of antiestrogens as cancer chemopreventive agents

4.4.1. Tamoxifen, the first chemopreventive SERM in high-risk pre- and postmenopausal women

4.4.2. Raloxifene and tamoxifen comparison

5. Conclusions

6. Reviewers

References

Vitae 


\section{Introduction}

Breast cancer is one of the most common forms of cancer observed in women. Endogenous estrogens are thought to play a major role in its development and estrogen receptor blockers are important drugs in its treatment [1-3]. It has been shown that longer exposures to estrogens result in an increased risk for breast cancer [4]. Estrogens have effects on many organ systems, beyond the reproductive system, in both females and males. Breast tissue is particularly dependent on circulating estrogens since there is no breast development in aromatase-deficient women and estrogen therapy of these patients leads to normal pre- and postpubertal breast development.

Estrogen effects are exerted through two types of specific receptor: estrogen receptor alpha (ER $\alpha)$ and beta $(E R \beta)$ [5-7]. These nuclear receptors are ligand-dependent transcription factors that mediate the biological effects of estrogens and antiestrogens (Figure 1).

Estrogen receptors act mainly by regulating the expression of target genes whose promoters contain specific sequences called estrogen-responsive element (ERE). After ERE-binding of ligand-bound ER dimers, modulation of transcription occurs via interaction with coactivators or corepressors. All together, these complexes play an important role in the recruitment of transcriptional machinery, the modulation of chromatine structure, and then in the regulation of ER target-gene expression [9]. The ER conformation differs with the type of ligand, and there is a marked difference in the topology of the ER surface between agonist- and antagonist-bound receptors [10-12]. Moreover, studies conducted with synthetic antiestrogens, such as tamoxifen, have shown that the agonist/antagonist profile of a ligand varies with the tissue and the target gene considered. This led to the term of selective estrogen receptor modulators (SERMs) to define this class of drug [13-15]. ER activity can also be modulated through indirect activation of the ER by growth factors or cytokines independently of the binding of natural or synthetic hormones [16, 17].

Another way for ERs to regulate gene expression involves protein-protein interactions with transcription factors acting in other transcriptional pathways. Such functional protein-protein interactions of ER have been described with transcription factors c-Jun [18-20], NFKB [21, 22], and Sp1 $[23,24]$. These interactions are modulated by receptor and ligand types. For example, differences between interactions of $E R \alpha$ and ER $\beta$ were found in the modulation of gene expression through AP1 sites since estradiol activated transcription only through $\mathrm{ER} \alpha$ [19].

Finally, estrogens also have very rapid effects outside the nucleus, so-called nongenomic effects [25]. For example, activities associated with protein-protein interactions between $\mathrm{ER} \alpha$ and membranerelated enzymes, normally activated by growth factors such as Src-PI3K-Akt or Src-Ras-ERK pathways, have been demonstrated [26, 27].

It has been proposed that ER $\beta$, the more recently discovered type, acts as a dominant regulator of estrogen signaling probably due to the formation of heterodimeric complexes [28]. The responses of $\mathrm{ER} \alpha$ and ER $\beta$ to agonists and antagonists differ according to inherent differences in the C-terminal ligand-binding domains of the receptors, whereas the magnitude of transcriptional activity is mainly influenced by AF-1 for ER $\alpha$, but not for ER $\beta$ [29]. 
To study the roles of each receptor in vivo, a series of mice were generated lacking either a functional $\mathrm{ER} \alpha$ or ER $\beta$ or both [5-7]. These mice have been useful in defining the tissue specificities, localization, and functions of each of the estrogen receptors. ER $\alpha$ and ER $\beta$ appear to play important, distinct and non-overlapping roles in the hypothalamus-preoptic area, the pituitary, the cardiovascular system and the gonads. These mouse models also show great promise for use in defining the effectiveness of putative therapeutic antiestrogens.

This review will summarize the expression of ERs in mammary tissues; their roles in the different steps of mammary carcinogenesis, particularly tumor growth and invasion; and the clinical consequences in cancer therapy and prevention.

\section{Expression of estrogen receptors in normal, premalignant and malignant mammary tissues}

\subsection{Normal mammary gland and premalignant lesions}

Estrogen and progesterone receptors are essential for mammary gland morphogenesis and physiological events such as puberty and pregnancy. Analysis of estrogen receptor proteins in rat mammary gland have shown that both ERs are expressed, and the results from ER $\alpha-K O$ and $E R \beta-K O$ mice reveal that $E R \alpha$ is necessary for mammary gland development. It has been suggested that $E R \beta$ co-expression with $E R \alpha$ represses $E R \alpha$ function and may contribute to the insensitivity of the mammary gland to estrogens during lactation [30]. However, in these studies no direct relationship between the presence of these receptors in mammary cells and estrogen-mediated proliferation was obtained by immunohistochemistry [31].

In humans, the major role of estrogens in normal pre- and postpubertal breast development has been evidenced by estrogen therapy of aromatase-deficient female patients [32]. The expression of the two subtypes of ER has been studied in surgical specimens from normal and premalignant tissues [33-36]. Ductal hyperplasia, atypical ductal hyperplasia, and ductal carcinoma in situ (DCIS) are risk factors for invasive breast cancer [37]. The genetic changes involved in the early development of these lesions and their progression to malignant or invasive disease are less defined for breast cancer than for other cancers. Most of the genes involved in mammary carcinogenesis are unknown, with the exception of the $\mathrm{BrCa} 1$ and $\mathrm{BrCa} 2$ genes in hereditary breast cancers (38). However, the analysis of genetic changes in premalignant lesions compared to adjacent invasive breast cancer supported the hypothesis that the putative precursors and the cancers are genetically related [39].

The expression of ER $\alpha$ and more recently ER $\beta$ were studied by immunohistochemistry in normal and premalignant tissues. The percentage of ER $\alpha$-positive cells is generally low (10-20\%) in normal resting mammary glands [33-36] and increases in proliferative benign disease, particularly when associated with atypia [34], and in low-grade DCIS. This has suggested that an elevated receptivity to estrogens in these tissues is involved in their higher risk of tumorigenesis [40]. In contrast to ER $\alpha$, the ER $\beta$ level decreased from proliferative ductal hyperplasia to DCIS, whereas in high-grade DCIS, both ER levels were low or absent [36]. Larger studies are required to determine whether the assays of the two ERs may be predictive of risk in premalignant lesions. 


\subsection{Invasive breast carcinoma: ERs as prognostic markers of primary breast cancers}

\subsubsection{ER $\alpha$ is associated with a favorable prognosis in primary breast cancers}

Estrogen and progesterone receptors (ER $\alpha$ and $\mathrm{PR}$ ) have now been studied in clinical breast cancer for more than 20 years. ER $\alpha$ are found in $50-80 \%$ of breast tumors and $E R \alpha$ status is essential in making decisions about endocrine therapy [2, 40]. Positive receptor status correlates with favorable prognostic features, including a lower rate of cell proliferation and histologic evidence of tumor differentiation. During the first several years after diagnosis, patients with ER-positive tumors tend to have a lower recurrence rate; however, this is balanced by a higher recurrence rate in subsequent years so that the overall prognostic significance of receptor status is modest. ER $\alpha$ and PR have their greatest utility in predicting response to hormonal therapy, both in the adjuvant setting and for advanced disease. Tumors that express both $\mathrm{ER} \alpha$ and $\mathrm{PR}$ have the greatest benefit from hormonal therapy, but those containing only ER $\alpha$ or PR still have significant responses [41].

Does the ER-negative tumor derive from ER-positive tumor or is it a totally different disease [42]? This question remains open since differences in ER $\alpha$ expression appear in tumors as early as carcinoma in situ [34] and the gene expression is substantially different in the two types of invasive carcinoma [43, 44]. Moreover, ER $\alpha$ re-expression in an ER $\alpha$-negative cancer cell is not sufficient to restore the ER $\alpha$ positive phenotype, particularly in terms of mitogenic response and the pattern of gene expression [45, 46].

\subsubsection{Expression of estrogen receptor $\beta$}

The second receptor, ER $\beta$, has likewise been detected in human breast cancers and may also contribute to hormonal sensitivity and resistance [47-49]. The clinical assay of this receptor has not been performed in large series. The initial studies by reverse transcription PCR analysis concerning the prognostic significance of ER $\beta$ were controversial. However, several studies indicated that the ER $\beta$ RNA level was decreased in invasive breast cancer tissues compared with the adjacent normal mammary gland [49]. The mechanism and role of the decrease in ER $\beta$ in carcinogenesis are unknown. However, these results are consistent with data from ER-KO mice, indicating a stimulatory role of ER $\alpha$ and an inhibitory effect of ER $\beta$ in the proliferation of different estrogen-target tissues [5-7]. Initial assays by immunohistochemistry in primary breast cancers indicate that $\mathrm{ER} \beta \square$ is not a surrogate for $\mathrm{ER} \alpha$ and, as thus may have its own clinical relevance in prognosis and tumor progression [50, 51].

\subsubsection{Expression of receptor splicing variants}

Numerous studies have identified variant $E R \alpha$ mRNAs in both neoplastic breast tissue and cell lines [reviewed in 52-53]. These mRNA variants lack one or several exons and are usually coexpressed with the wild-type $E R \alpha$ message. Although the existence of $E R \alpha$ variant proteins was initially 
controversial, there is now considerable evidence for their expression in normal and neoplastic tissues. Differences in ER $\alpha$ levels measured with an amino-terminal antibody as compared with a carboxy-terminal one [54] suggested the expression of several types of truncated ER $\alpha$ mRNA splice variants lacking one or more exons. Using several antibodies, the endogeneous proteins encoded by the $E R \alpha \Delta 3$ (second zinc finger deleted) [55], and ER $\alpha \Delta$ (hormone binding domain altered) [52, 56] were detected in breast cancer tumors and those encoded by ER $\alpha \Delta$ (hormone binding domain altered) were detected in ovarian tumors [57]. When expressed individually in cell lines, these variants are shown to modulate the activity of the intact receptor on ERE response, but also have intrinsic activity.

Since the discovery of ER $\beta$, several groups have reported the cloning of differently sized ER $\beta$ isoforms [6, 58-61], some with extended $\mathrm{N}$-termini and others with truncation or insertion in the C-terminal ligand-binding domain. It is not known if all these receptor forms exist in tissue but they could have a significant role if heterodimerization occurs with the wild-type receptor. The clinical relevance of these variants in the prognosis of primary breast cancer is not known.

\section{Estrogens and their receptors in breast cancer progression: a dual role in cancer proliferation and invasion}

\subsection{Estrogens increased ER-positive breast cancer cell growth}

\subsubsection{Direct evidences of the mitogenic effect of estrogens}

Estrogens have repeatedly been shown to stimulate the growth of breast cancers since the initial works of Beatson [62] and Lacassagne [63]. The mechanism underlying this effect was specified when ER-positive breast cancer cell lines became available. Estrogens directly increased the growth of breast cancer cells in culture by increasing the number of G0/G1 cells entering into the cell cycle [64, 65]. Antiestrogens are competitive inhibitors of endogenous estrogens and inhibit the mitogenic activity of estrogens in breast cancer. On a molecular basis, they trigger inactive conformation of the ER $\alpha$, which is then unable to activate transcription via activating function AF2 [9-11, 15-17]. It should be noted that some partial agonist/antagonists such as tamoxifen present an agonist activity on some tissues, such as the uterus, probably through activation of the AF1 function of the ER $\alpha$ [66]. In this way, tamoxifen activates the transcription of genes preferentially controlled by AF1.

These initial data obtained in cell lines or animal tissues were largely confirmed by clinical studies developed with this compound in the last decades. Tamoxifen appears to be an antagonist in the breast and a partial agonist in uterus and bone.

\subsubsection{Involved mechanisms?}

The mechanism underlying the mitogenic action of estrogens has been widely studied in cell lines and probably results from the complex modulation by the ERs of different transcriptional pathways-thus 
involving the regulation of a multitude of genes. The initial and current hypothesis is that estrogens control the growth of primary breast cancers by inducing estrogen-regulated proteins that function as autocrine, paracrine or intracrine growth factors [65]. Estrogens activate (and antiestrogens block) genes controlled by estrogen-responsive elements (EREs). In addition to these classical transcriptional effects, these ligands can also modulate other genes, not containing ERE, via direct protein-protein interaction of ER with other transcription factors. For example, ER $\alpha$ interferes with AP1-directed gene activity [20-22] through a protein-protein interaction with c-Jun. In cell cultures, genes such as cyclin D1 are stimulated by estrogens through an AP-1 pathway and repressed by tamoxifen [67]. By contrast, the non-genomic effects of estrogens on signal transduction do not appear implicated in their mitogenic action, since all key events in cell cycle stimulation can occur in the presence of a MAP kinase-activating inhibitor [68].

The genes responsible for the mitogenic effect of estrogens have not been definitively determined but they probably include secreted growth factors [65], growth factor receptors [69, 70], proteases such as cathepsin D [71] and cyclin/cdk factors [67]. The implication of molecules interfering with the cytoskeleton, such as E-cadherin, a mediator of cell-cell interactions, as been also suggested [72]. Ecadherin is down-regulated by estrogens in normal and tumorigenic breast epithelial cells [73, 74]. Moreover, most of these estrogen-regulated proteins are differentially expressed in ER-positive and ER-negative tumors [43] and this probably contributes to their different metastatic potentials. Actual molecular profiling of breast tumors based on new screening technologies would complete the set of genes associated with different phenotypes [75].

\subsection{Are anti-invasive effects mediated by estrogen receptors responsible for their association with a favorable prognosis of breast cancers?}

\subsubsection{Clinical data supporting the hypothesis that estrogens prevent invasion}

There is a great deal of evidence to support the hypothesis that estrogens are important because they are potent mitogens for normal breast epithelial cells, and it is believed that the duration of breast epithelium exposure to estrogens is a significant risk factor for breast cancer development. However, in mammary carcinogenesis, even though the mitogenic effect of estrogens is well demonstrated, the presence of ER $\alpha$ is associated with more differentiated and less invasive tumors and a more favorable prognosis.

Moreover, there is some clinical evidence indicating that estrogens and their receptors protect against invasion. Epidemiological studies have evaluated the breast cancer risk in women using hormone replacement therapy (HRT) where $80 \%$ were taking preparations containing estrogen alone [76, 77]. Among the women using HRT, the risk of breast cancer slightly increased, but the tumors under estradiol treatment were confined to localized disease with more favorable prognosis. Tumors in HRTusers were less invasive to axillary lymph nodes and to more distant sites. Other studies of tamoxifen therapy of primary breast cancer suggest that tamoxifen increased the spreading of ER $\alpha$-positive primary tumor cells to contralateral sites. Tamoxifen use decreased ( 0.8 fold) the risk of ER $\alpha$-positive 
contralateral breast tumors, but it appeared to increase $(4.9$-fold) the risk of ER $\alpha$-negative contralateral tumors [78]. All together, these clinical data are in agreement with an anti-invasive effect of estrogens.

These observations have also been confirmed by data from several laboratories, including ours, bringing in vitro evidence of the anti-invasive effects mediated by estrogen receptors. In human breast cancer cell lines, ER $\alpha$ expression was associated with low invasiveness and low motility in culture tests $[44,79]$. Moreover, when ER $\alpha$-positive cells were implanted in nude mice, tumors appeared only in the presence of estrogens and are poorly metastatic as compared to those developed from ER $\alpha$ negative breast cancer cell lines [80]. The protective role of ERs against tumor invasion and metastasis was further studied by analyzing the effect of estradiol and ERs on cancer cell motility and invasiveness in different breast cancer cell lines.

\subsubsection{Estrogen receptors inhibit invasion through two distinct mechanisms in the presence or absence of hormone}

\subsubsection{Estrogens inhibit invasion via ERE-regulated genes}

The effects of estrogens on cell invasiveness have been studied in vitro using a two-chamber culture model and Matrigel, a reconstituted basement membrane. The initial studies indicated that the invasiveness of MCF7 breast cancer cells was increased by antiestrogens [81, 82]. More recent studies have demonstrated that estradiol significantly reduces invasiveness and that this inhibition is reversed by antiestrogens [83-87]. This conclusion was noted in several ER $\alpha$-positive cancer cell lines established from breast [83] or ovary [85], and in different ER $\alpha$-negative cancer cells constitutively expressing $E R \alpha$ after stable transfection $[45,84,87]$. Similar results were also obtained on the migration of normal cells from vascular smooth muscle [86]. These in vitro data were confirmed in nude mice, since the formation of experimental lung metastases from metastatic ER $\alpha$-negative MDAMB-231 breast cancer cells was inhibited by estradiol after ER $\alpha$ expression by transfection [45, 87]. In contrast to the effects of estradiol on growth, which are opposite in native ER-positive cells (stimulation) and ER-transfected cells (repression), it should be noted that this hormone induces the same anti-invasive effect in both cell types. This suggests that different pathways control cell proliferation and cell invasion.

The mechanism by which estradiol inhibits invasion was studied using a new invasion assay based on the transient expression of ER $\alpha$ in the ER $\alpha$-negative MDA-MB-231 cell line [88, 89]. Estradiol treatment decreased by 2-fold the invasiveness in ER $\alpha$ transfectant (Figure 2). The inhibitory effect of estradiol is reversed by both types of antiestrogens, $\mathrm{OH}$-tamoxifen (4-hydroxytamoxifen, the active metabolite of tamoxifen) and ICI 164,384, a pure antiestrogen. By contrast, estradiol or antiestrogen treatments did not significantly affect invasion of control ER-negative cells. Moreover, the analysis of different $\mathrm{ER} \alpha$ deletion mutants strongly suggested that some estrogen-regulated genes negatively control invasion since the integrity of the hormone-binding domain, the DNA-binding domain and 
activating function 2 (AF2) of ER $\alpha$ was required [89]. In contrast, the $\mathrm{N}$-terminal domain containing the AF1 function is not involved since a deletion $\triangle \mathrm{AB}$ mutant was as efficient as the wild-type receptor.

As possible candidates among estrogen-regulated proteins, those that increase cell-cell adhesion, such as E-cadherin, or that decrease matrix degradation, such as $\alpha 1$-antichymotrypsin, should be considered [reviewed in 83, 90].

\subsubsection{Estrogen receptors inhibit invasion independently of ligand binding:} involvement of protein-protein interactions

Using the transfection/invasion method described above, we also demonstrated that expression of unliganded $E R \alpha$ and several mutants deleted in the hormone-binding domain drastically reduced MDA-MB-231 cell invasiveness in Matrigel tests. As shown in Figure 2, in estrogen-deprived conditions, transient wild type ER $\alpha$ expression induced a 3 -fold decrease in the invasiveness of transfected cells and estradiol treatment reinforced the ligand independent effect by an additional 2fold reduction. The strong inhibition due to the unliganded ER $\alpha$ is reversed by the pure antiestrogen $\mathrm{ICl} 164,384$ which is known to decrease receptor concentration but not by $\mathrm{OH}$-tamoxifen. In breast cancer cells, OH-tamoxifen and other tamoxifen derivatives were shown to up-regulate the receptor by decreasing its degradation (91).This increase of ER $\alpha$ concentration could explain the anti-invasive properties of tamoxifen in certain models in vitro (92) and could participate to its beneficial effects in vivo.

The domain involved in ligand-independent inhibition of invasion has been further characterized by progressive deletions in the ER $\alpha$ sequence. As shown in Figure 3, the first zinc finger of the DNAbinding domain (i.e., amino acids 179-215) is responsible for the anti-invasive activity. This activity is independent of the two key aminoacids which are essential for ERE binding and the estrogen specificity of the responses [93]. Among the different nuclear receptors, invasion was specifically decreased by the expression of ER $\alpha$ (3-fold) and to a lesser extent by ER $\beta$ (2-fold), but was not affected by thyroid hormone receptor $\alpha 1$, vitamin $D$ receptor, retinoid acid receptor $\alpha$, or glucocorticoid and androgen receptors. On the basis of these data, it was proposed that unliganded ER decreases invasiveness via interaction of the first zinc finger region with an unknown nuclear factor.

Moreover, immunocytochemical studies of ER $\alpha$-positive breast cancer cell lines (MCF7, ZR75.1, T47D) indicated that in hormone-deprived conditions, ER $\alpha$ expression was inversely correlated with cell motility [89]. Migrating cells had lower ER levels than non-migrating cells. Finally, treatments such as phorbol ester or pure antiestrogen, known to decrease ER $\alpha$ levels in MCF7 breast cancer cells, significantly increased in vitro invasiveness $[79,89]$. Taken together, these in vitro data indicate a protective role of $\mathrm{ER} \alpha$ against the invasiveness of breast cancer cells.

These data obtained on cell cultures cannot be extrapolated to the in vivo situation, where the endocrine and paracrine effects of estrogens may have major consequences on the invasiveness of cancer cells. However, their possible implications in the monitoring of breast cancer should be discussed. Particularly, negative effects should be anticipated in the clinical use of pure antiestrogens such as ICI 164,384 or ICI 182,780, since these drugs increased in vitro cancer cell invasiveness by 
inhibiting the protective effect of both estrogens and ER $\alpha$ by decreasing its content. ER $\alpha$ expression should perhaps also be preserved in cancer cells during adjuvant therapies in order to maintain differentiation and a low invasive potential. In addition, these results suggest new therapeutic strategies based on $\mathrm{ER} \alpha$ re-expression to prevent the proliferation, invasiveness and metastatic potency of ER $\alpha$-negative breast cancer cells [90].

\subsection{Role of estrogen receptor variants in cancer progression?}

\subsubsection{Splicing variants of ER alpha and beta}

Numerous studies have identified variant ER $\alpha$ and ER $\beta$ mRNAs in both neoplastic breast tissue and cell lines $[52,53]$. These mRNA variants lack one or several exons and are usually coexpressed with the wild-type ER message. However, the pathophysiological significance of ER $\alpha$ variant expression is unclear. Several studies using transient transfection have shown that individual ER $\alpha$ variant proteins can have positive or negative effects on the wild-type ER $\alpha$ activity $[52,53]$. The efficacy of these variants depends on their relative levels as compared to the wild-type protein, and a 10-20-fold excess might be necessary for significant activity [55]. The presence of one or more variant proteins in variable levels in normal breast epithelium and neoplastic tissue could infuence the wild-type receptor, but it has not yet been demonstrated that these variants are involved in estrogen-independent growth or antiestrogen resistance. The variants ER $\Delta 3$ (lacking the second zinc finger) and ER $\Delta 4$ (deleted in the hormone-binding domain) are overexpressed in normal cells but not in breast cancer cells. These variants, which contain the first zinc finger domain, could have an invasion-suppression activity independent of the hormone action. This was verified by expression of the ER $\Delta 3$ variant [55]. A more detailed clinical evaluation of the $E R \alpha$ and $E R \beta$ variants is required to determine their influence in the different steps of mammary carcinogenesis and the response to therapy.

\subsubsection{Mutants with point mutation}

It has been estimated that only $1 \%$ of primary breast tumors contain missense mutations of the ER $\alpha$ gene [94]. These mutations may be more frequent in metastatic breast lesions and could affect normal $E R \alpha$ function. Unfortunately, functional studies with most ERs containing missense mutations have not yet been reported. Studies performed with the Tyr537Asn indicate that this mutant exhibited a potent, hormone-independent transcriptional activity probably due to a conformational change in the receptor molecule that mimics hormone binding [95]. A hypersensitive ER mutant Lys303Arg has been found in premalignant breast lesions, suggesting a role in early carcinogenesis [96]. This suggests that these somatic mutations, although infrequent, may significantly alter the evolution of individual tumors.

\section{Antiestrogen approaches for breast cancer therapy and prevention}

\subsection{Tamoxifen and other adjuvant therapies of breast cancer}


The antiestrogen tamoxifen has been in use for more than two decades to treat hormone-dependent breast cancers [97-99]. Its undeniable value has been demonstrated in two settings. In the first, tamoxifen is used as a systemic adjuvant therapy after surgery for early breast cancer, where, after 5 years of treatment, it reduces disease recurrence and improves survival regardless of patient age and nodal status [98]. Second, in patients with metastatic disease who have ER-positive tumors, tamoxifen is effective in approximately $50 \%$ of the cases [2, 3, 40, 100].

In adjuvant therapy, the benefit of 5 years of tamoxifen has been evidenced in the presence and absence of chemotherapy in terms of the frequency of relapse and survival. More prolonged tamoxifen therapy has no additional advantage through 4 years of follow-up. However, the addition of tamoxifen to chemotherapy in patients with estrogen receptor-negative tumors resulted in no significant advantage over that achieved from chemotherapy alone [100]. This verifies the concept that tamoxifen treatment is a mechanism-based therapy of functional estrogen receptors. The promising use for tamoxifen for ductal carcinoma in situ or breast cancer prevention has also been noted in certain patient groups [101].

Alternatives to tamoxifen therapy include the use of new SERMs and aromatase inhibitors. The ideal SERM would fully block ERs in the breast cancer tumor but would not cross the blood-brain barrier and thus would not stimulate hot flashes by blocking the effects of estrogens in the brain, nor would it stimulate endometrial proliferation. In addition, this agent would have no harmful effects on blood lipids or bone density. The search for this ideal SERM has led to the development of pure antagonists that exhibit no agonist activity in any tissue yet measured. The first pure ER antagonist, ICI 164,384, was described by Wakeling and Bowler [102] and this was followed by fulvestrant (Flaxodel ${ }^{\mathrm{TM}}, \mathrm{ICI}^{182,780}$ ) with increased antiestrogenic activity. Fulvestrant was formulated by adding a long-chain alkyl moiety at the 7-alpha position of 17-beta-estradiol (Figure 4). It is devoided of estrogen agonist activity in a large number of in vitro and in vivo preclinical models. In animal models, it does not cross the bloodbrain barrier and appears to be neutral with respect to lipids and bone. Fulvestrant down-regulates the estrogen receptor and is active in tamoxifen-resistant breast cancer cell lines. Clinical studies have demonstrated that this agent is active in second-line therapy after tamoxifen failure [103] but as yet it has been shown no efficacy and limited safety in pre-menopausal women. Other SERMs are in development, with the goal of reducing toxicity and/or improving efficacy as compared to tamoxifen.

In premenopausal women, alternatives to tamoxifen include ovarian suppression with luteinizing hormone-releasing hormone (LHRH) agonists, ovarian ablation and progestins. A recent study involving patients with metastatic disease indicated a higher survival with the combination of tamoxifen and ovarian suppression versus tamoxifen alone [100]. The efficacy of new aromatase inhibitors in premenopausal women has not been established but the first-line generation agent aminoglutethimide was not effective. The recent studies indicating that progestin associated to estrogen increases breast cancer incidence and mortality in HRT users [104, 105] also raises questions about the use of progestin in breast cancer therapy of premenopausal women.

Randomized trials are needed to define the optimal sequencing of the available endocrine agents such as nonsteroidal aromatase inhibitors and tamoxifen in postmenopausal women and to compare 
alternative regimens of tamoxifen combined with ovarian ablation or $\mathrm{LHRH}$ analogue in premenopausal women.

\subsection{Aromatase inhibitors}

New adjuvant strategies include the use of aromatase inhibitors in place of, or in addition to, tamoxifen, and the use of adjuvant bisphosphonates. The third generation of inhibitors include the steroidal drug exemestane and the nonsteroidal drugs letrozole and anastrozole. These very potent inhibitors of aromatase decrease estrogen levels below the level of detection of most clinical assays. All three agents have been found to be equivalent or superior to megestrol acetate as a second line therapy for metastatic breast cancer. In the first line setting, anastrozole and letrozole, are now considered more effective than tamoxifen as first-line therapy for metastatic breast cancer in postmenopausal women, regardless of whether the patients have received tamoxifen as adjuvant therapy [103, 106]. These aromatase inhibitors are less associated than tamoxifen with serious side effects, such as endometrial cancers and thromboembolic complications [107]. Letrozole is more effective as a neoadjuvant endocrine therapy than tamoxifen for ErbB-1- and/or ErbB-2-positive and ER-positive primary breast cancer [108]. This suggests that the growth-promoting effects of these receptor tyrosine kinases are estrogen-dependent.

The mechanisms of ER signaling inhibition by tamoxifen and aromatase inhibitors probably differ on multiple aspects since these two classes of drugs alter differently the conformation of the estrogen receptors and consequently the nature of the interacting cofactors. The types of tumor resistance induced by these treatments are different as evidenced by the efficacy of aromatase inhibitors on tamoxifen-resistant tumors. However, the use of aromatase inhibitors is at the expense of accelerated bone loss, and strategies to minimize this side effect are under investigation [107]. Adjuvant bisphosphonates have been found to reduce the bone loss associated with cancer treatments and their efficacy is now being evaluated in adjuvant trials in early breast cancer [109]. Whether or not the higher efficacy of aromatase inhibitors over SERMs is confirmed in postmenopausal women, it would be interesting to study their effects on ER $\alpha$ expression, as well as the potential role of adrenal androgens such as 5-androstenediol, which have an affinity for ER $\alpha$ similar to that of tamoxifen [110, 111].

\subsection{Second therapy for antiestrogen resistant tumors}

A significant proportion of ER-positive tumors are resistant to tamoxifen therapy either at the first treatment or after an initial positive response [112]. Other SERMs, such as triphenylethylene derivatives of tamoxifen (Toremifene, Idoxifene) and benzothiophenes like raloxifene, were crossresistant with tamoxifen, which implied that neither would be effective as second-line therapy [98, 99]. The pure antiestrogens have been developed to prevent the growth of tamoxifen-resistant tumors. Fulvestrant was the first pure antagonist tested in tamoxifen-resistant breast carcinoma. Phase III trials have been conducted comparing fulvestrant with the aromatase inhibitor, anastrozole, in 
postmenopausal patients with advanced breast cancer progressing after prior endocrine therapy. Objective response and median response duration were similar in fulvestrant-treated and anastrozoletreated patients [112]. New non-steroidal antiestrogens, EM 800 and its active derivative EM-652, are also pure antagonists with a higher affinity for ER than fulvestrant or estradiol. These compounds are under evaluation in preclinical models [113].

The cross-talk of estrogen receptors with growth factor signalling pathway is well demonstrated and appears implicated in breast cancer progression and tamoxifen resistance. Overexpression of growth factor receptor causes resistance to tamoxifen through protein kinase activation. Moreover, preclinical studies indicated that inhibitors of growth factor tyrosine kinase have the potential to delay or even reverse tamoxifen resistance (98). Clinical trials combining kinase inhibitors and endocrine therapies should afford a possibility to modulate simultaneously two different pathways implicated in cancer progression.

\subsection{Implication of estrogens in breast cancer carcinogenesis and use of antiestrogens as cancer chemopreventive agents}

Estrogens may increase breast cancer risk by acting at different steps of mammary carcinogenesis [4]: as a pre-initiator when the exposure occurs during fetal life, as an initiator by inducing DNA damage through formation of free radicals, or as a mitogen by stimulating the growth of existing malignant cells.

4.4.1. Tamoxifen, the first chemopreventive SERM in high-risk pre- and postmenopausal women

The extensive use of the long-term adjuvant tamoxifen has revealed that this selective estrogen receptor modulator (SERM) produces antiestrogenic actions in the breast but estrogen-like actions in bone, and lowers serum cholesterol. These properties not only allowed the application of tamoxifen but also the development of raloxifene to prevent osteoporosis with the potential to prevent breast cancer in postmenopausal women.

In a North American breast cancer prevention trial, tamoxifen reduced the incidence of ER-positive breast cancer among all women by $62 \%$ [114]. A similar reduction was found among healthy $\mathrm{BrCa} 2$ carriers [115]. In contrast, tamoxifen use beginning at age 35 years or older did not reduce breast cancer incidence among healthy women with inherited BrCa1 mutations [115].

\subsubsection{Raloxifene and tamoxifen comparison}

Raloxifene is a second-generation SERM that has estrogenic effects on bone and lipid metabolism, and antiestrogenic effects on breast tissue. Unlike tamoxifen, raloxifene displays antiestrogenic effects on the endometrium and may serve as a safer alternative to tamoxifen in prevention [116]. A randomized placebo-controlled trial with 3 years of raloxifene treatment was conducted to demonstrate that this 
SERM efficiently prevents osteoporosis in postmenopausal women. As a secondary end point, this trial also showed that raloxifene reduces the risk of both in situ and invasive breast cancer by $65 \%$. The risk of developing estrogen receptor (ER)-positive cancers was significantly decreased by 10 -fold. Raloxifene was shown to reduce breast cancer risk regardless of lifetime estrogen exposure, but the reduction was greater in those with higher lifetime exposure to estrogens [117]. Whether this benefit is due to a decrease in carcinogenesis or to lower tumor growth will be specified in the next few years. Finally, the comparison of tamoxifen and raloxifene in breast cancer prevention has now been initiated by enrolling cancer-free but high-risk postmenopausal women [118].

In addition to raloxifene, other classes of chemopreventive agents are being studied. Future directions include combined therapies by the addition of an aromatase inhibitor to a SERM.

\section{Conclusions}

Experimental and clinical data have demonstrated the importance of ER in the development and progression of breast cancer and this has led to its becoming a major target for breast cancer treatment. The efficacy of antiestrogen treatment to inhibit (and probably prevent) the growth of ERpositive breast cancer cells has been extensively documented. However, ER status is generally associated with more differentiated and less invasive tumors, suggesting that it may have a protective role against metastatic progression. The exact role of ER expression in the differences observed between ER-positive and ER-negative tumors, such as gene expression and genomic mutations, remains unknown. Estrogens and their receptors probably have a complex action in breast cancer cells. We present here a dual role as mitogen and anti-invasive agent, but estrogens likely affect other steps involved in cancer progression, such as angiogenesis [119] and immune response [120]. Estrogens inhibit invasiveness via a classical activation of ERE-regulated genes, whereas the unliganded receptor acts through interaction with an unknown protein. Non-classical mechanisms of action, in which the receptor may bind to other transcription factors instead of DNA or to the proteins involved in pathways such as motility and invasion, are now being investigated. The identification of the factors that inhibit the invasiveness of ER $\alpha$-positive cells would be a useful step in the development of new therapeutic targets to cure the most aggressive ER $\alpha$-negative tumors.

\section{References}

[1] Pike MC, Krailo MD, Henderson BE, Casagrande JT, and. Hoel DG. Hormonal risk factors, breast tissue age and the age-incidence of breast cancer. Nature 1983;303:767-770.

[2] Mc Guire WL. Hormone receptor: their role in predicting prognosis and response to endocrine therapy. Semi Oncol 1978;5:2428-2433.

[3] Fisher B, Jeong JH, Dignam J, et al. Findings from recent National Surgical Adjuvant Breast and Bowel Project adjuvant studies in stage I breast cancer. J Natl Cancer Inst Monogr 2001;30:62-66.

[4] Henderson IC. Risk factors for breast cancer development. Cancer 1993;71:2127-2140.

[5] Korach KS. Insights from the study of animals lacking functional estrogen receptor. Science 1994;266:1524-1527.

[6] Gustafsson JA. Estrogen receptor B-a new dimension in estrogen mechanism of action. J Endocrinol 1999;163:379-383. 
[7] Dupont S, Krust A, Gansmuller A, Dierich A, Chambon P, Mark M. Effect of single and compound knockouts of estrogen receptors $\alpha(E R \alpha)$ and $B(E R B)$ on mouse reproductive phenotypes. Development 2000;127:4277-4291.

[8] Kumar V, Green S, Stack G, Berry M, Jin JR, Chambon P. Functional domains of the estrogen receptor. Cell 1987;51:941-951.

[9] McKenna NJ, Lanz RB, O'Malley BW. Nuclear receptors coregulators: cellular and molecular biology. Endocr Rev 1999;20:321-344.

[10] Shiau AK, Barstad D, Loria PM, et al. The structural basis of estrogen receptor/coactivator recognition and the antagonism of this interaction by tamoxifen. Cell 1998;95(7):927-37

[11] Brzozowski AM, Pike AC, Dauter Z, et al. Molecular basis of agonism and antagonism in the oestrogen receptor. Nature 1997;389:753-758.

[12] Moras D, Gronemeyer $H$. The nuclear receptor ligand-binding domain: structure and function. Curr Opin Cell Biol 1998;10:384-91.

[13] Katzenellenbogen BS, Katzenellenbogen JA. Biomedicine. Defining the "S" in SERMs. Science 2002;295:2380-2381.

[14] McDonnell DP, Connor CE, Wijayaratne A, Chang CY, Norris JD. Definition of the molecular and cellular mechanisms underlying the tissue-selective agonist/antagonist activities of selective estrogen receptor modulators Recent Prog Horm Res 2002;57:295-316.

[15] MacGregor JI, Jordan VC. Basic guide to the mechanisms of antiestrogen action. Pharmacol Rev 1998;50:151-96.

[16] Kato S, Endoh H, Masuhiro $\mathrm{Y}$, et al. Activation of the estrogen receptor through phosphorylation by mitogen activated protein kinase. Science 1995; 270:1491-1494.

[17] Bunone G, Briand PA, Miksicek RJ, Picard D. Activation of the unliganded estrogen receptor by EGF involves the MAP kinase pathway and direct phosphorylation. EMBO $\mathrm{J}$ 1996;15:21742183.

[18] Gaub MP, Bellard M, Scheuer I, Chambon P,Sassone-Corsi P. Activation of the albumin gene by the estrogen receptor involves the Fos-Jun complex. Cell 1990;63:1267-1276.

[19] Paech K, Webb P, Kuiper GG, et al. Differential ligand activation of estrogen receptors ER $\alpha$ and ERß at AP1 sites. Science 1997;277:1508-1510

[20] Teyssier C, Belguise K, Galtier F, Chalbos D. Characterization of the physical interaction between estrogen receptor $\alpha$ and JUN proteins J Biol Chem 2001;276:36361-36369.

[21] Ray A, Prefontaine KE, Ray P. Down-modulation of interleukin-6 gene expression by $17 \beta \square$ estradiol in the absence of high affinity DNA binding by the estrogen receptor. J Biol Chem 1994;269:12940-12946

[22] Stein B, Yang MX. Repression of the interleukin-6 promoter by estrogen receptor is mediated by NF-KB and C/EBP $\beta \square \square$ Mol Cell Endocrinol 1995;15:4971-4979.

[23] Batistuzzo de Medeiros SR, Krey G, Hihi AK, Wahli W. Functional interactions between the estrogen receptor and the transcription activator $S p 1$ regulate the estrogen-dependent transcriptional activity of the vitellogenin A1 promoter. J Biol Chem 1997;29:18250-18260

[24] Porter W, Saville B, Hoivik D, Safe S. Functional synergy between the transcription factor Sp1 and the estrogen receptor. Mol Endocrinol 1997;11:1569-1580.

[25] Pietras R, Szego C. Specific binding sites for oestrogen at the outer surfaces of isolated endometrial cells. Nature 1977;265:69-72.

[26] Simoncini T, Hafezi-Moghadam A, Brazil DP, Ley K, Chin WW, Liao JK. Interaction of estrogen receptor with the regulatory subunit of phosphatidylinositol-3-OH kinase. Nature 2000;407:538-541.

[27] Kousteni S, Bellido T, Plotkin LI, et al. Nongenotropic, sex-nonspecific signaling through the estrogen and androgen receptors: dissociation from transcriptional activity. Cell 2001;104:719-730.

[28] Cowley SM, Parker MG. A comparison of transcriptional activation by ER $\alpha$ and ERß. J Steroid Biochem Mol Biol, 1999;69:165-175.

[29] Pettersson K, Delaunay F, Gustafsson JA. Estrogen receptor beta acts as a dominant regulator of estrogen signaling. Oncogene $2000 ; 43: 4970-4978$.

[30] Saji S, Jensen EV, Nilsson S, Rylander T, Warner M, Gustafsson JA. Estrogen receptors $\alpha$ and B in the rodent mammary gland. Proc Natl Acad Sci USA, 2000;97:337-342.

[31] Clarke RB, Howell A, Potten CS, Anderson E. Dissociation between steroid receptor expression and cell proliferation in the human breast. Cancer Res 1997;57:4987-4991.

[32] Meinhardt $U$, Mullis PE. The essential role of the aromatase/p450arom. Semin Reprod Med 2002;20:277-84. 
[33] Khan SA, Rogers MA, Khurana KK, Meguid MM, Numann PJ. Estrogen receptor expression in benign breast epithelium and breast cancer risk. J Natl Cancer Inst 1998;90: 37-42.

[34] Roger P, Daures JP, Maudelonde T, et al. Dissociated overexpression of cathepsin-D and estrogen receptor $\alpha$ in preinvasive mammary tumors. Hum Pathol 2000;31:593-600.

[35] Shoker BS., Jarvis C, Clarke RB, et al. Estrogen receptor-positive proliferating cells in the normal and precancerous breast. Am J Pathol 1999;155:1811-1815.

[36] Roger P, Esslimani Sahla M, Mäkelä S, Gustafsson JA, Baldet P, Rochefort H. Decreased expression of estrogen receptor $B$ protein in proliferative preinvasive mammary tumors. Cancer Res 2001;61:2537-41.

[37] Dupont WD, Page DL. Risk factors for breast cancer in women with proliferative breast disease. N Engl J Med, 1985;312:146-151.

[38] Hilakivi-Clarke L. Estrogens, BRCA1, and breast cancer. Cancer Res 2000;60:4993-5001.

[39] O'Connell P, Pekkel V, Fuqua SA, Osborne CK, Clark GM, Allred DC. Analysis of loss of heterozygosity in 399 premalignant breast lesions at 15 genetic loci. J Natl Cancer Inst 1998;90:697-703.

[40] Osborne CK. Steroid hormone receptors in breast cancer management. Breast Cancer Res Treat 1998;51:227-38

[41] Bardou VJ, Arpino G, Elledge RM, Osborne CK, Clark GM. Progesterone receptor status significantly improves outcome prediction over estrogen receptor status alone for adjuvant endocrine therapy in two large breast cancer databases. J Clin Oncol 2003;21:1973-1979.

[42] Zhu K, Bernard LJ, Levine RS, Williams SM. Estrogen receptor status of breast cancer: a marker of different stages of tumor or different entities of the disease? Med Hypotheses 1997;49(1):69-75.

[43] Sheikh MS, Garcia M, Pujol P, Fontana JA, Rochefort H. Why are estrogen-receptor-negative breast cancers more aggressive than the estrogen-receptor-positive breast cancers? Invasion Metastasis 1994;14:329-36.

[44] Thompson EW, Paik S, Brünner N, et al. Association of increased basement membraneinvasiveness with absence of estrogen receptor and expression of vimentin in human breast cancer cell lines. J Cell Physiol 1992;150:534-544.

[45] Garcia, M, Derocq D, Freiss G, and Rochefort H. Activation of estrogen receptor into a receptornegative breast cancer cell line decreases the metastatic and invasive potential of the cells. Proc Natl Acad Sci USA 1992;89:1538-11542.

[46] Jiang SY, Jordan VC Growth regulation of estrogen receptor negative breast cancer cells transfected with cDNA's for estrogen receptor. J Natl Cancer Inst 1992;84:580-591

[47] Taylor AH, Al-Azzawi F. Immunolocalisation of oestrogen receptor B in human tissues. J Mol Endocrinol 2000;24:145-155.

[48] Jarvinen TA, Pelto-Huikko M, Holli K, Isola J. Estrogen receptor B is coexpressed with ER $\alpha$ and $\mathrm{PR}$ and associated with nodal status, grade, and proliferation rate in breast cancer. Am J Pathol 2000;156:29-35.

[49] Palmieri C, Cheng GJ, Saji S, et al. Estrogen receptor beta in breast cancer. Endocr Relat Cancer 2002;9:1-13.

[50] Hayashi SI, Eguchi H, Tanimoto K, et al. The expression and function of estrogen receptor alpha and beta in human breast cancer and its clinical application. Endocr Relat Cancer 2003;10:193-202.

[51] Fuqua SA, Schiff R, Parra I, et al. Estrogen receptor beta protein in human breast cancer: correlation with clinical tumor parameters. Cancer Res 2003;63:2434-2439.

[52] Fuqua SA, Wolf DM. Molecular aspects of estrogen receptor variants in breast cancer. Breast Cancer Res Treat 1995;35:233-241.

[53] Murphy LC, Leygue E, Dotzlaw H, Douglas D, Coutts A, Watson PH. Oestrogen receptor variants and mutations in human breast cancer. Ann Med 1997;29:221-234.

[54] Huang A, Leygue ER, Snell L, Murphy LC, Watson PH. Expression of estrogen receptor variant messenger RNAs and determination of estrogen receptor status in human breast cancer. Am J Pathol 1997;150:1827-1833.

[55] Erenburg I, Schachter B, Mira y Lopez R, Ossowski L. Loss of an estrogen receptor isoform (ER alpha delta 3) in breast cancer and the consequences of its reexpression: interference with estrogen-stimulated properties of malignant transformation. Mol Endocrinol 1997;11:2004-2015.

[56] Desai AJ, Luqmai YA, Walters JE et al. Presence of exon 5-deleted oestrogen receptor in human breast cancer: functional analysis and clinical significance. Brit J Cancer 1997;75:1173-1184. 
[57] Park W, Choi JJ, Hwang ES, Lee JH. Identification of a variant estrogen receptor lacking exon 4 and its coexpression with wild-type estrogen receptor in ovarian carcinomas. Clin Cancer Res 1996;2:2029-2035.

[58] Ogawa S, Inoue S, Watanabe T, et al. Molecular cloning and characterization of human estrogen receptor betacx: a potential inhibitor of estrogen action in human. Nucleic Acids Res 1998;26:3505-3512.

[59] Saji S, Omoto $\mathrm{Y}$, Shimizu C, et al. Expression of estrogen receptor (ER) (beta)cx protein in ER(alpha)-positive breast cancer: specific correlation with progesterone receptor. Cancer Res 2002;62:4849-53.

[60] Poola I, Abraham J, Liu A. Estrogen receptor beta splice variant mRNAs are differentially altered during breast carcinogenesis. J Steroid Biochem Mol Biol 2002;82:169-79.

[61] OmotoY, Eguchi H, Yamamoto-Yamaguchi Y, Hayashi S. Estrogen receptor (ER) beta1 and ER betacx/beta2 inhibit ERalpha function differently in breast cancer cell line MCF7. Oncogene 2003;22:5011-5020.

[62] Beatson GT. On the treatment of inoperable cancer of the mamma: suggestion for a new method of treatment with illustrative cases. Lancet 1896;ii:104-107.

[63] Lacassagne A. Hormonal pathogenesis of adenocarcinoma of the breast. Am J Cancer 1936;2:217-225.

[64] Doisneau-Sixou SF, Sergio CM, Carroll JS, Hui R, Musgrove EA, Sutherland RL. Estrogen and antiestrogen regulation of cell cycle progression in breast cancer cells. Endocr Relat Cancer 2003;10:179-186.

[65] Dickson RB, Lippman ME. Growth factors in breast cancer. Endocr Rev 1995;16:559-589.

[66] Berry M, Metzger D, Chambon P. Role of the two activating domains of the oestrogen receptor in the cell-type and promoter-context dependent agonistic activity of the anti-oestrogen 4hydroxytamoxifen. EMBO J 1990;9:2811-8.

[67] Prall OW, Rogan EM, Sutherland RL. Estrogen regulation of cell cycle progression in breast cancer cells. J Steroid Biochem Molec Biol 1998;65:169-174.

[68] Caristi S, Galera JL, Matarese F et al. Estrogens do not modify MAP kinase-dependent nuclear signaling during stimulation of early $\mathrm{G}(1)$ progression in human breast cancer cells. Cancer Res 2001;61:6360-6366.

[69] Lee AV, Jackson JG, Gooch JL, et al. Enhancement of Insulin-Like Growth Factor Signaling in Human Breast Cancer: Estrogen Regulation of Insulin Receptor Substrate-1 Expression in Vitro and in Vivo. Mol Endocrinol 1999;13:787-796.

[70] Pegram MD, Slamon DJ. Combination therapy with trastuzumab (Herceptin) and cisplatin for chemoresistant metastatic breast cancer : evidence for receptor-enhanced chemosensitivity. Seminars Oncol 1999;26:89-95.

[71] Rochefort H, Liaudet E, Garcia M. Alterations and role of human cathepsin D in cancer metastasis. Enzyme Protein 1996;49:106-16.

[72] Mareel M, Leroy A. Clinical, cellular, and molecular aspects of cancer invasion. Physiol Rev 2003;83:337-76.

[73] Blaschuk OW, Munro SB, Farookhi R. E-cadherin, estrogens and cancer: is there a connection ? Can J Oncol 1994;4:291-301.

[74] Oesterreich S, Deng W, Jiang S, et al. Estrogen-mediated down-regulation of E-cadherin in breast cancer cells. Cancer Res 2003;63:5203-5208.

[75] Gruvberger S, Ringner M, Chen Y, et al. Estrogen receptor status in breast cancer is associated with remarkably distinct gene expression patterns. Cancer Res. 2001;61:5979-84

[76] Marsden J, Backs NPM. Hormone replacement therapy and breast cancer. Endocr Relat Cancer 1996;3:81-97.

[77] Collaborative group on hormonal factors in breast cancer. Lancet 1997;350:1047-1059.

[78] Li Cl, Malone KE, Weiss NS, Daling JR. Tamoxifen therapy for primary breast cancer and risk of contralateral breast cancer. J Natl Cancer Inst 2001;13:1008-1013.

[79] Platet N, Prevostel C, Derocq D, Joubert D, Rochefort H, Garcia M. Breast cancer cell invasiveness: correlation with protein kinase $\mathrm{C}$ activity and differential regulation by phorbol ester in estrogen receptor-positive and -negative cells. Int J Cancer 1998;75:750-756.

[80] Price JE, Polyzos A, Zhang RD, Daniels LM. Tumorigenicity and metastasis of human breast carcinoma cell lines in nude mice. Cancer Res 1990;50:717-721.

[81] Albini A, Graf J, Kitten GT, et al. 17 $\beta$-Estradiol regulates and v-Ha-ras transfection constitutively enhances MCF7 breast cancer cell interactions with basement membrane. Proc Natl Acad Sci USA 1986;83:8182-8186. 
[82] Thompson EW, Reich R, Shima TB, et al. Differential regulation of growth and invasiveness of MCF-7 breast cancer cells by antiestrogens. Cancer Res 1998;48:6764-6768.

[83] Rochefort H, Platet N, Hayashido $\mathrm{Y}$, et al. Estrogen receptor mediated inhibition of cancer cell invasion and motility: an overview. J Steroid Biochem Molec Biol 1998;65:163-168.

[84] Garcia M, Derocq D, Platet N, et al. Both estradiol and tamoxifen decrease proliferation and invasiveness of cancer cells transfected with a mutated estrogen receptor. J Steroid Biochem Molec Biol 1997;61:11-17.

[85] Hayashido Y, Lucas A, Rougeot C, Godyna S, Argraves WS, Rochefort H Estradiol and fibulin-1 inhibit motility of human ovarian- and breast-cancer cells induced by fibronectin. Int $\mathrm{J}$ Cancer 1998;75:654-658

[86] Kolodgie FD, Jacob A, Wilson PS, et al. R Estradiol attenuates directed migration of vascular smooth muscle cells in vitro. Am J Pathol 1996;148:969-976.

[87] Long BJ, Rose DP. Invasive capacity and regulation of urokinase-type plasminogen activator in estrogen receptor (ER)-negative MDA-MB-231 human breast cancer cells, and a transfectant (S30) stably expressing ER. Cancer Lett 1996;99:209-215.

[88] Platet, N, Garcia, M. A new bioassay using transient transfection for invasion-related gene analysis. Invasion Metastasis 1999;18:198-206.

[89] Platet N, Cunat S, Chalbos D, Rochefort H, Garcia, M. Unliganded and liganded estrogen receptors protect against cancer invasion via different mechanisms Mol Endocrinol 2000;14:999-1009.

[90] Garcia M, Rochefort H. Estrogen receptor targeted therapies of breast cancer. Cur Opin Oncol Endocr Metab Invest Drugs 2000;2:60-67.

[91] Laios I, Journe F, Laurent G, Nonclercq D, Toillon RA, Seo HS, Leclercq G. Mechanisms governing the accumulation of estrogen receptor alpha in MCF-7 breast cancer cells treated with hydroxytamoxifen and related antiestrogens. J Steroid Biochem Mol Biol 2003;87:207221.

[92] Bracke ME, Charlier C, Bruyneel EA, Labit C, Mareel MM, Castronovo V. Tamoxifen restores the E-cadherin function in human breast cancer MCF-7/6 cells and suppresses their invasive phenotype. Cancer Res 1994;54:4607-4609.

[93] Green S, Kumar V, Theulaz I, Wahli W, Chambon P. The N-terminal DNA-binding 'zinc finger' of the oestrogen and glucocorticoid receptors determines target gene specificity. EMBO J 1988;7:3037-44.

[94] Roodi N, Bailey LR, Kao WY, et al. Estrogen receptor gene analysis in estrogen receptor-positive and receptor-negative primary breast cancer. J Natl Cancer Inst 1995;87:446-451.

[95] Zhang QX, Borg A, Wolf DM, Oesterreich S, Fuqua SAW. An estrogen receptor mutant with strong hormone-independent activity from a metastatic breast cancer. Cancer Res 1997;57:1244-1249.

[96] Fuqua SA, Wiltschke C, Zhang QX, et al. A hypersensitive estrogen receptor-alpha mutation in premalignant breast lesions. Cancer Res 2000;60:4026-4029.

[97] Early Breast Cancer Trialists' Collaborative Group. Tamoxifen for early breast cancer: An overview of the randomized trials. Lancet 1998;351:1451-1467.

[98] Come SE, Buzdar AU, Arteaga CL et al. Second international conference on recent advances and future directions in endocrine manipulation of breast cancer: summary consensus statement. Clin Cancer Res 2003;9:443-446.

[99] Jordan VC, Murphy CS. Endocrine pharmacology of antiestrogens as antitumor agents. Endocrine Reviews 1990;11:578-610.

[100] Fisher B, Anderson S, Tan-Chiu E, et al. Tamoxifen and chemotherapy for axillary nodenegative, estrogen receptor-negative breast cancer: findings from National Surgical Adjuvant Breast and Bowel Project B-23. J Clin Oncol 2001;4:931-942.

[101] Schwartz GF. Consensus conference on the classification of ductal carcinoma in situ : the current treatment of ductal carcinoma in situ. Breast $\mathrm{J}$ 2001;7:308-10.

[102] Wakeling AE, Bowler J. ICI 182,780, a new antioestrogen with clinical potential. J Steroid Biochem Mol Biol 1992;43:173-177.

[103] Robertson JF, Osborne CK, Howell A, et al. Fulvestrant versus anastrozole for the treatment of advanced breast carcinoma in postmenopausal women: a prospective combined analysis of two multicenter trials. Cancer. 2003;98:229-238.

[104] Rossouw JE, Anderson GL, Prentice RL, et al. Risks and benefits of estrogen plus progestin in healthy postmenopausal women: principal results from the women's health initiative randomized controlled trial. JAMA 2002;288:321-333. 
[105] Beral V Million Women Study Collaborators. Breast cancer and hormone-replacement therapy in the Million Women Study. Lancet 2003;362:419-427.

[106] Mouridsen H, Gershanovich M, Sun Y, et al. Superior efficacy of letrozole versus tamoxifen as first-line therapy for postmenopausal women with advanced breast cancer: results of a phase III study of the International Letrozole Breast Cancer Group. J Clin Oncol 2001;10:2596-2606.

[107] Santen RJ. Inhibition of aromatase: insights from recent studies. Steroids 2003;68:559-567.

[108] Ellis MJ, Coop A, Singh B, et al. Letrozole is more effective neoadjuvant endocrine therapy than tamoxifen for ErbB-1- and/or ErbB-2-positive, estrogen receptor-positive primary breast cancer: evidence from a phase III randomized trial. J Clin Oncol 2001;18:3808-3816.

[109] Coleman RE. Should bisphosphonates be the treatment of choice for metastatic bone disease? Semin Oncol 2001;28:35-41.

[110] Rochefort H, Garcia M. The estrogenic and antiestrogenic activities of androgens in female target tissues. Pharmacol Ther 1983;23:193-216.

[111] Adams J, Garcia M, Rochefort H. Estrogenic effects of physiological concentrations of 5androstene-3 beta, 17 beta-diol and its metabolism in MCF7 human breast cancer cells. Cancer Res 1981;41:4720-4726.

[112] Osborne CK, Pippen J, Jones SE, et al. Double-blind, randomized trial comparing the efficacy and tolerability of fulvestrant versus anastrozole in postmenopausal women with advanced breast cancer progressing on prior endocrine therapy: results of a North American trial. J Clin Oncol 2002;16:3386-3395.

[113] Gutman M, Couillard S, Labrie F, Candas B, Labrie C. Effect of treatment sequence with radiotherapy and the antiestrogen EM 800 on the growth of ZR 751 human mammary carcinoma in nude mice. Int J Cancer 2003;103:268-276.

[114] Fisher B, Costantino JP, Wickerham DL, et al. Tamoxifen for prevention of breast cancer: report of the National Surgical Adjuvant Breast and Bowel Project P-1 study. J Natl Cancer Inst 1998;90:1371-1388.

[115] Tamoxifen and breast cancer incidence among women with inherited mutations in BRCA1 and BRCA2: National Surgical Adjuvant Breast and Bowel Project (NSABP-P1) Breast Cancer Prevention Trial. JAMA 2001;286:2251-2256.

[116] Park WC, Jordan VC. Selective estrogen receptor modulators (SERMS) and their roles in breast cancer prevention. Trends Mol Med 2002;8:82-88.

[117] Cauley JA, Norton L, Lippman ME et al. Continued breast cancer risk reduction in postmenopausal women treated with raloxifene: 4-year results from the MORE trial. Breast Cancer Res Treat 2001;65:125-134.

[118] Vogel VG, Costantino JP, Wickerham DL, Cronin WM, Wolmark N. The study of tamoxifen and raloxifene: preliminary enrollment data from a randomized breast cancer risk reduction trial. Clin Breast Cancer 2002;2:153-159.

[119] Losordo DW, Isner JM. Estrogen and angiogenesis: a review. Arterioscler Thromb Vasc Biol 2001;21:

12.http://cancerres.aacrjournals.org/cgi/ijlink?linkType=ABST\&journalCode=atvbaha\&resid=21/1/6

[120] Castagnetta L, Granata OM, Traina A, et al. A role for sex steroids in autoimmune diseases: a working hypothesis and supporting data. Ann N Y Acad Sci. 2002;966:193-203.

\section{Vitae}

Platet: Nadine Platet, Ph.D. in 1998, is a Research Engineer at the National Institute for Health and Medical Research (INSERM), Laboratory of Preclinical Neurosciences, Unit 318, Grenoble, France.

Cathiard: Anne-Marie Cathiard, Ph.D. in 1981, is a Study Engineer at the National Institute for Health and Medical Research (INSERM), Laboratory of Molecular and Cellular Endocrinology of Cancers, Unit 540, Montpellier, France. She has had a long-standing involvement in research on steroid hormone action and endocrinology.

Gleizes: Michel Gleizes is a laboratory technician at the University of Montpellier, France, with experience in immunohistochemistry, protein biochemistry and cell biology. 
Garcia: Marcel Garcia, Ph.D. in 1981, is a Director of Research at the National Institute for Health and Medical Research (INSERM), Laboratory of Molecular and Cellular Endocrinology of Cancers, Unit 540, Montpellier, France. His current research interest is hormone dependency and the metastatic progression of breast and ovarian cancers. Specifically, his investigations focus on target genes such as cathepsin D and estrogen receptors for therapeutic applications. He has published over 130 scientific papers and chapters in the fields of endocrinology and oncology. 


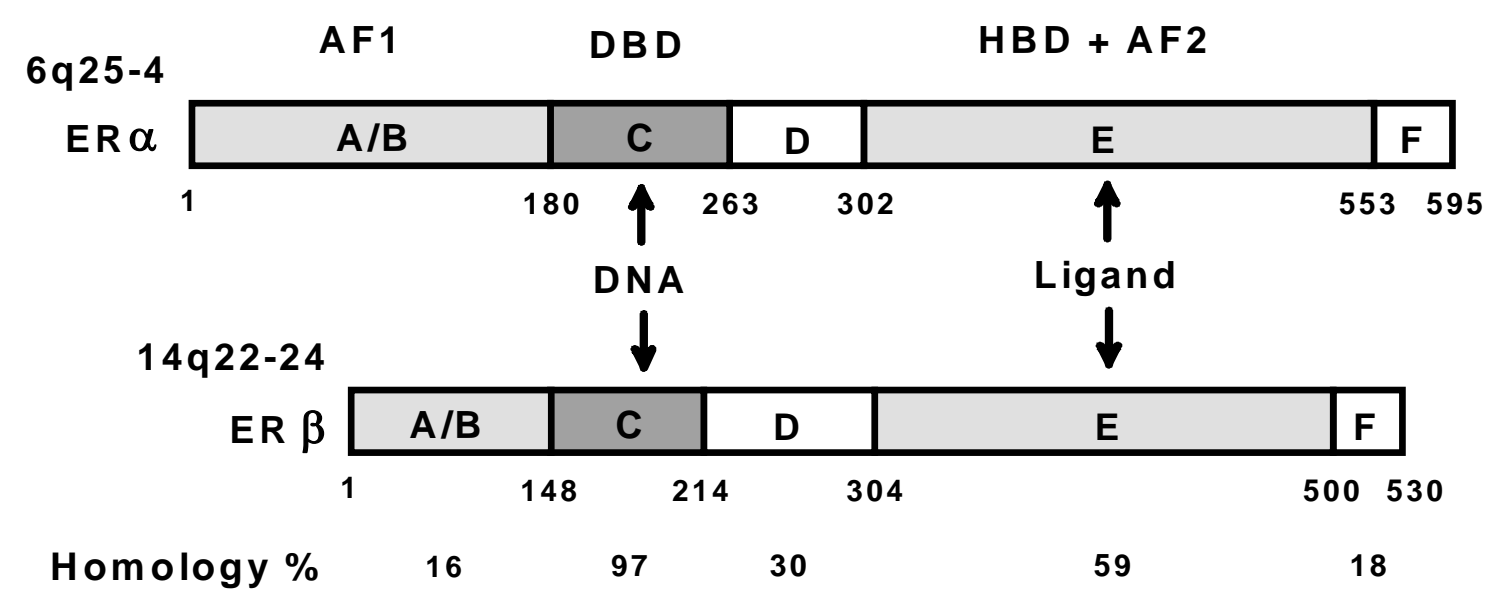

Figure 1: Structures and functions of estrogen receptors

The human estrogen receptors $E R \alpha$ and $E R \beta$ contain five functional domains ( $A$ to $E$ ) as other members of the nuclear receptor superfamily and an additional domain $F$ in their $C$ terminal part [8-16]. The binding of estrogen in the hormone binding domain (HBD) induces a trans conformational change of the whole molecule allowing unmasking of the activating function 1 (AF1) in domain $A / B$ by removal of chaperone (HSP90), dimerization, activation of activating function 2 (AF2) in the C-terminal part of the $\mathrm{E}$ domain and binding to estrogen-responsive element (ERE) on DNA via domain $\mathrm{C}$. 


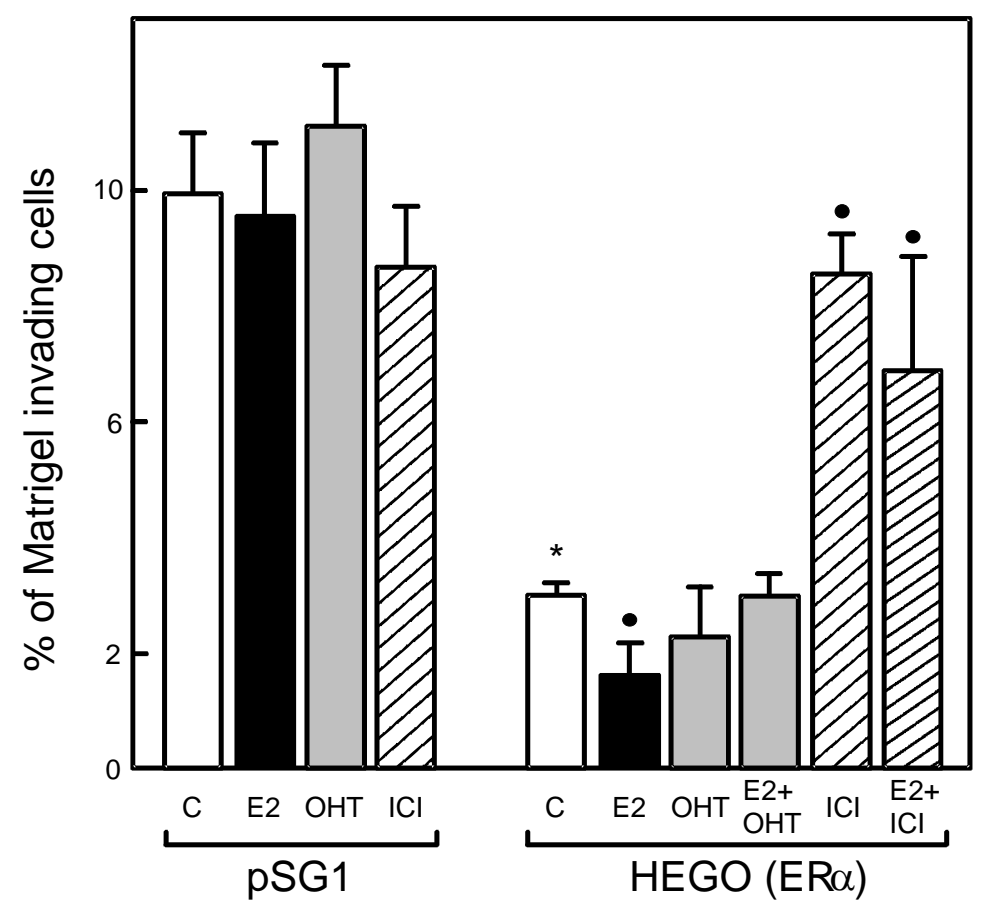

Figure 2: Effect of ER $\alpha$ expression and estradiol treatment on MDA-MB-231 cell invasion.

$E R \alpha$-negative MDA-MB-231 cells were transiently cotransfected with ER $\alpha$-expressing vector (HEGO) or control vector (pSG1), and a luciferase expressing vector used as a marker of transfected cells [88]. The percentage of cells invading Matrigel was estimated in the presence of $20 \mathrm{nM}$ estradiol (E2), 100 nM 4-hydroxy-tamoxifen (OHT), $100 \mathrm{nM} \mathrm{ICl} \mathrm{164,384} \mathrm{(ICl)} \mathrm{or} \mathrm{ethanol} \mathrm{alone} \mathrm{(C).} \mathrm{*} p<0.01$ versus pSG1 control; • $\mathrm{p}<0.05$ versus HEGO control. Reproduced from [89, copyright 2000, Endocrine Society]. 


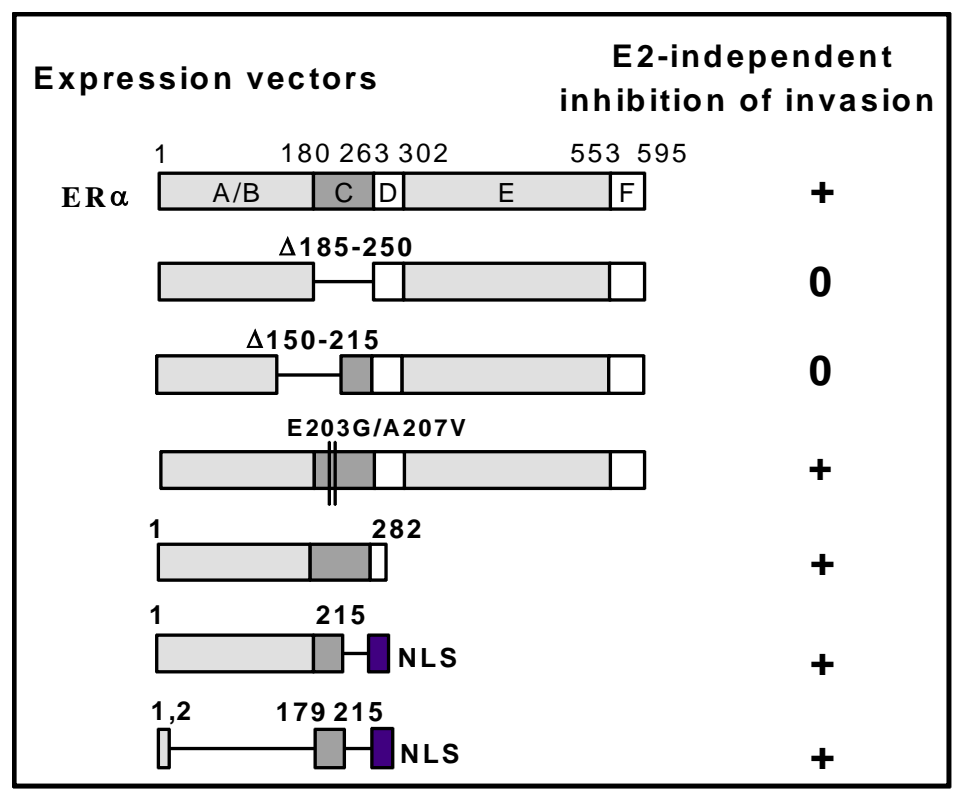

Figure 3: E2-independent inhibition of cancer cell invasion by ER $\alpha$ requires the first zinc finger region.

Effects of ER $\alpha$ mutants on MDA-MB-231 breast cancer cell invasiveness were determined in transfection/invasion assay. + for active mutant, 0 for inactive mutant. NLS = nuclear localization signal. Reproduced from [89, copyright 2000, Endocrine Society]. 
<smiles>CC12CCC3c4ccc(O)cc4CCC3C1CCC2O</smiles>

Estradiol<smiles>CCC(=C(c1ccc(O)cc1)c1ccc(O)cc1)c1ccccc1</smiles>

(4-OH) Tamoxifen

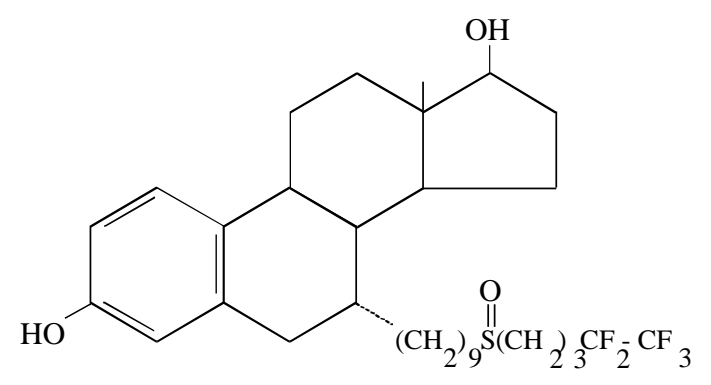

Fulvestrant/Faslodex (ICl 182,780)

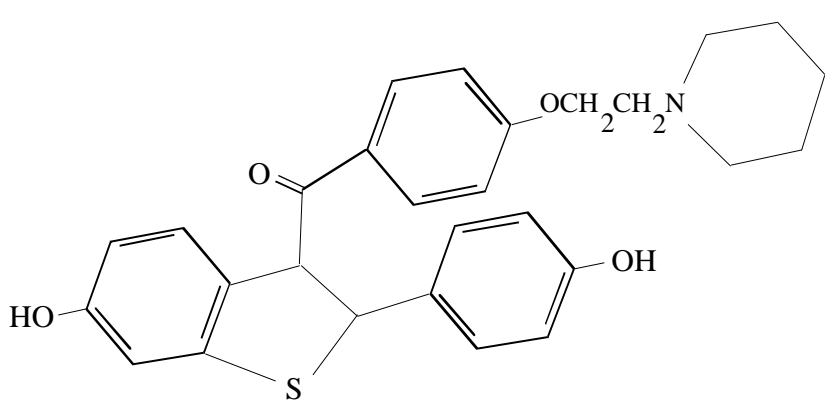

Raloxifene (LY 157,758)

Figure 4: Structure of estradiol and major SERM used in therapy. 